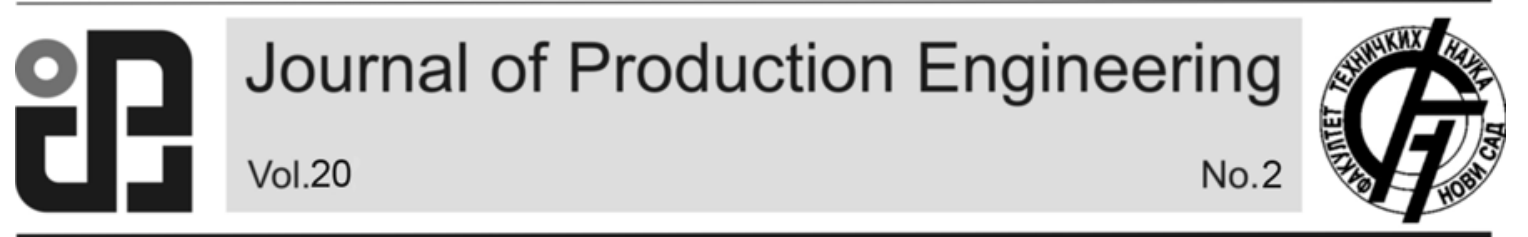

JPE (2017) Vol.20 (2)

Rizvi, S.A., Ali, W.

Original Scientific Paper

\title{
DETERMINATION THE EFFECT OF MACHINING PARAMETERS ON ROUGHNESS IN TURNING OPERATION OF DIN 17210 STEEL USING TAGUCHI TECHNIQUE
}

\author{
Received: 09 Nevember 2017 / Accepted: 12 December 2017
}

\begin{abstract}
In this research work an attempt has been made to try to investigate the effects of cutting parameters such as feed rate cutting speed and depth of cut on surface roughness in turning operation of $16 \mathrm{MnCr} 5$ steel, is a case hardening steel with by the support of Taguchi technique. An orthogonal array, signal to noise $(S / N)$ ratio and analysis of variance (ANOVA) were used to determine the effects and contributions of cutting speed, feed rate and depth of cut on the response variable. Turning operations were carried out by Tungsten carbide coated cutting tool inserts. The experiments were conducted at three different cutting speeds (400, 600 and 800 rpm) with three different feed rates $(0.06,0.12$ and $0.18 \mathrm{~mm} / \mathrm{rev})$ and a constant depth of cut $(0.5,1.0$ and $1.5 \mathrm{~mm})$. The cutting parameters are optimized using signal to noise ratio and the analysis of variance.obtained result data revelled that depth of cut has most significant effect over surface roughness followed by cutting speed while feed rate has lowest effect.
\end{abstract}

Key words: $16 \mathrm{MnCr} 5$ steel, Regression analysis, Surface Roughness, Taguchi, optimization, ANOVA

Određivanje uticaja parametara obrade na hrapavost pri operacijama struganja čelika DIN 17210 korišćenjem Taguchi tehnike. U ovom istraživačkom radu napravljen je pokušaj da se ispita efekat parametara rezanja, kao što su pomak, brzina rezanja i dubina rezanja na hrapavosti površine pri struganju 16MnCr5 čelika, koji je ojačan, pomoću podrške Taguchi metode. Ortogonalni niz, odnos signala i šuma (S/N) $i$ analiza varijanse (ANOVA) korišćeni su za određivanje uticaja $i$ doprinosa brzine rezanja, pomaka $i$ dubine rezanja na varijablu odziva. Pločice sa prevlakom od karbidnih vlakana su korišćene kao alat za rezanje. Eksperimenti su izvedeni sa tri različite brzine rezanja (400, $600 i 800$ obrtaja u minuti) sa tri različita pomaka (0.06, $0.12 i 0.18 \mathrm{~mm} / \mathrm{o}) i$ konstantne dubine rezanja $(0.5,1.0$ i $1.5 \mathrm{~mm})$. Parametri rezanja se optimiziraju korišćenjem odnosa šuma signala $i$ analize varijanse. Dobijeni rezultati rezultata otkrivaju da dubina rezanja ima najznačajniji uticaj na hrapavost površine, nakon čega sledi brzina rezanja, dok pomak ima najmanji efekat.

Ključne reči: $16 \mathrm{MnCr} 5$ čelik, regresiona analiza, površinska hrapavost, Taguchi, optimizacija, ANOVA

\section{INTRODUCTION}

In modern industry the goal is to manufacture any item/products at low cost, with high quality in short time. Turning is a very important machining operation employed to remove the extra material from the periphery of work piece. Surface roughness is an important quality parameter of turned/machined surface. Selection of correct combination of cutting parameters will help the machinist to complete the operation in minimum possible time maintaining the required value of surface roughness.In turning operation, parameters such as cutting speed, feed, and depth of cut, cutting tool geometry and materials as well as use of any cutting fluids will impact the material removal rates and the machining qualities like the surface roughness, the roundness of circular and dimensional deviations of the product.

Carmita Camposeco-Negrete [1] conducted the experiments to optimize the cutting parameters for minimizing energy consumption in turning of AISI $6061 \mathrm{~T} 6 \mathrm{Al}$ with the support of orthogonal array, signal to noise $(\mathrm{S} / \mathrm{N})$ ratio and analysis of variance (ANOVA) and they observed that feed rate is the most significant factor for minimizing energy consumption and surface roughness. Srinivas Athreya and Y. D. Venkatesh [2] worked on lathe facing of mild steel. The objective of his work was to obtain optimum cutting conditions to get minimum surface roughness in facing of mild steel. Taguchi method was applied in this experimental design work. From the experiment it was finalised that, cutting speed has the most significant role on quality of surface roughness followed by depth of cut. D. Philip Selvaraj et al [3] optimized the surface roughness, cutting force and tool wear in tuning of duplex stainless steel and authors mentioned in their result that the feed rate is the more significant parameter influencing the surface roughness and cutting force and predicted results are found to be closer to experimental results within $8 \%$ deviations. Mathematical model developed with the help of RSM. K. Adarsh Kumar et al. [4] performed research work to analyze, how surface finish of EN-8 is affected by speed, feed, depth of cut on the basis of multiple regression analysis and analysis of variance. Chorng-Jyh Tzeng et al [5] coupled Taguchi technique with grey relation analysis to optimize machining parameters which affect the surface roughness of SKD 11 is a high carbon high chromium alloy tool steel and finally the identified that depth of cut was the most influence on the roughness average and the cutting speed was the most influential factor to the roughness 
maximum and the roundness. Additionally, the analysis of variance (ANOVA) is also applied to identify the most significant factor. S. Arul [6] worked on optimization of machining parameters of glass fiber reinforced polymer. The data of machining parameters, tool life, thrust force and torque was analysed and optimized by using a algorithm which is based on group method data handling system. M.P. Jenarthanan [7] performed an experimental work to investigate the machining parameters in milling operation of glass fibers reinforced plastics (GFRP). For this tool used were solid carbide end mill tools. It was observed that, Feed rate was the machining parameter that has the highest influence on specific cutting force and surface roughness followed by the helix angle of the cutter. Saadat Ali Rizvi and Wajahat Ali [8] optimize the machining parameters in turning of IS2062 steel with Taguchi technique for dry turning operation and they mentioned in their result that cutting speed having significant effect on tool wear followed by feed rate.R. Suresh et al. [9] conducted experimental work on AISI 4340 steel with the help of RSM method. They concluded that to minimise surface roughness and cutting forces, it is necessary that low feed rate, high cutting speed, low depth of cut and short machining time are employed and to minimize tool wear low cutting speed and low feed rate required. S.Z. Chavoshi and M. Tajdari [10], worked on AISI 4140 steel by using CBN cutting tool on lathe machine. They analysed that hardness has most significant effect on roughness of surface produced after machining operation. Anil Gupta et al. [11] performed a research work and concluded that, the cutting speed of 160 $\mathrm{m} / \mathrm{min}$, feed $0.1 \mathrm{~mm} / \mathrm{rev}$, nose radius $0.8 \mathrm{~mm}$, the depth of cut of $0.2 \mathrm{~mm}$ and a cryogenic environment are the most favourable machining parameters for the turning of AISI P -20 steel on CNC. Sahin et al. [12] worked on a model of the surface roughness for machining of mild steel by using TiN-coated carbide tool. In result they concluded that roughness of surface increases with increase in feed rate and surface roughness decreases with increase in depth of cut and depth of cut. Saadat Ali Rizvi, Wajahat Ali [13] optimized machining parameters which affect the surface roughness of EN 8steel in CNC turning operation, for this purpose they applied Taguchi technique and they produced a elation ship between the depth of cut and surface roughness and inform that on increasing the depth of cut surface roughness also increases. Murat Sarıkaya and Abdulkadir Güllü [14] studied the effect of the main turning parameters such as, cutting speed, feed rate, depth of cut and cooling condition on arithmetic average roughness $\left(R_{a}\right)$ and average maximum height of the profile $\left(R_{z}\right)$ when turning of AISI 1050 Steel and they informed that feed rate was most effective parameters on the surface roughness.

Cooling conditions are significantly effective on the surface roughness. MQL is a good tool in order to increase of the machined surface quality for cutting operations. M. Venkata Ramana and Y. ShanmukaAditya [15] worked on titanium alloys to determine the effect of process parameters on surface roughness during tuning operation and from result it was observed that feed rate is contributed more as compared to cutting speed and depth of cut to minimize surface roughness for both uncoated and coated tools.

\section{TAGUCHI METHOD}

This method is developed by Dr. Genichi Taguchi born in 1924 in Japan. This is a Fractional Factorial design method based on orthogonal array. In general main effects and interaction of two factors is considered and it is assumes that some higher order interactions are not much important. This method is used to find best set of values of controllable factors to make the design less sensitive with variation of noise, means Taguchi make a design more robust.

\subsection{Signal-to-Noise ratio:}

Main performance measuring character of Taguchi is signal-to-Noise ratio or simply known as $\mathrm{S} / \mathrm{N}$ ratio. It is used to reduce variation of signal and to optimize the input factors for producing best possible response. There are three possible case for $\mathrm{S} / \mathrm{N}$ ratio calculation-

i) Smaller-the-Better: It is used to minimize the response, means where output is undesirable.

$$
S N R=-10 \log _{10}\left[\frac{\sum y_{i}^{2}}{n}\right]
$$

ii) Larger-the-Better: This is used to maximize the response, means where output is desirable. This case can be converted is Smaller-is-Better when we take reciprocal of all measured data and calculate the $\mathrm{S} / \mathrm{N}$ ratio as Smaller-is-Better.

$$
S N R=-10 \log _{10}\left[\frac{\sum \frac{1}{y_{i}^{2}}}{n}\right]
$$

iii) Nominal-the-Better: This is used when neither a smaller and nor a larger value is required for response.

$$
S N R=10 \log _{10}\left[\frac{\bar{y}^{2}}{\sigma^{2}}\right]
$$

\section{Where:}

$$
\begin{array}{ll}
y & \text { Measured output data of experiment } \\
y_{i} & \text { Measured output data of } \mathrm{i}^{\text {th }} \text { experiment } \\
\bar{y} & \text { Mean of measured output data of experiments } \\
\sigma & \text { Standard deviation } \\
\sigma^{2} & \text { Variance }
\end{array}
$$

\section{ANALYSIS OF VARIANCE}

It is also known as ANOVA. It is used to check whether means of more than two set quantities are equal or not with the help of F-test. It is a statistical tool applied on result of Taguchi experiment to determine percentage contribution of factors. It use $\mathrm{S} / \mathrm{N}$ ratio of Taguchi method for this calculation. 


\section{MATERIAL}

Workpiece material used in presented work is $16 \mathrm{MnCr} 5$ which is a low alloy case hardening steel. It is used for the purpose of toughness and wear resistance. This material is used to manufacture camshaft, axle and crankshaft etc.fig 1 shown the work piece material after turning operation.

\begin{tabular}{|c|c|c|c|c|c|}
\hline $\mathrm{C} \%$ & $\mathrm{Mn} \%$ & $\mathrm{Si} \%$ & $\mathrm{P} \%$ & $\mathrm{~S} \%$ & $\mathrm{Cr} \%$ \\
\hline 0.14 & 1.00 & 0.40 & 0.035 & 0.035 & 0.80 \\
to & to & & & & to \\
0.19 & 1.30 & & & & 1.10 \\
\hline
\end{tabular}

Table 1. Chemical composition of $16 \mathrm{MnCr} 5$

Chemical composition and mechanical properties of parent material is shown in Table 1 and Table 2 respectively.

\begin{tabular}{|l|l|}
\hline Young s modulus & $2 \times 10^{5} \mathrm{MPa}$ \\
\hline Tensile strength & $650-880 \mathrm{MPa}$ \\
\hline Yield strength & $350-550 \mathrm{MPa}$ \\
\hline
\end{tabular}

Table 2. Mechanical Properties of $16 \mathrm{MnCr} 5$

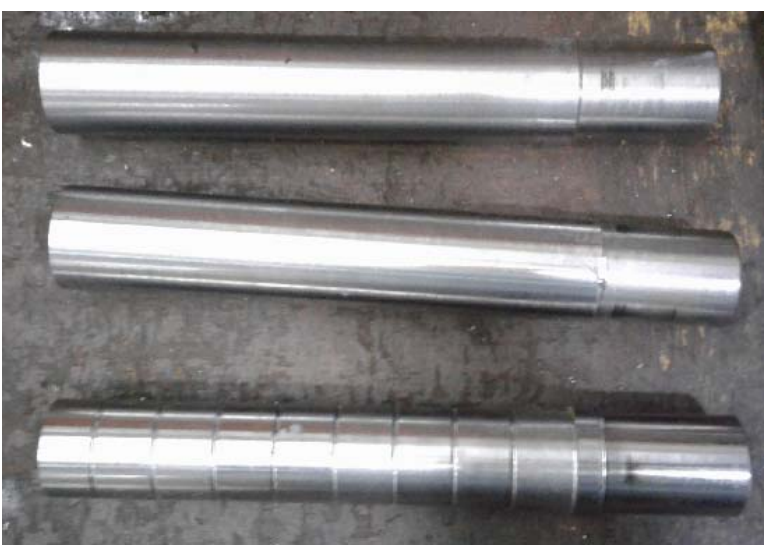

Fig. 1. Work piece after turning

\section{SELECTION OF FACTORS AND THEIR LEVELS}

Cutting speed in rpm, feed in $\mathrm{mm} / \mathrm{rev}$ and depth of cut in $\mathrm{mm}$ selected as factors for design of experiment and roughness of machined surface as response. The turning parameters used and their levels chosen are listed in Table 3.

\begin{tabular}{|c|c|c|c|c|}
\hline Factors & Notation & $\begin{array}{c}\text { Level } \\
1\end{array}$ & $\begin{array}{c}\text { Level } \\
2\end{array}$ & $\begin{array}{c}\text { Level } \\
3\end{array}$ \\
\hline Speed (rpm) & N & 400 & 600 & 800 \\
\hline Feed (mm/rev) & F & 0.06 & 0.12 & 0.18 \\
\hline Depth of cut $(\mathrm{mm})$ & D & 0.5 & 1.0 & 1.5 \\
\hline
\end{tabular}

Table 3. Factors and their levels

\section{SELECTION OF ORTHOGONAL ARRAY}

For design of experiment by using Taguchi method we select a $\mathrm{L}_{27}$ array. Total number of experiments performed in experimental work is equal to 27 .

\begin{tabular}{|c|c|c|c|}
\hline $\begin{array}{c}\text { Sl. } \\
\text { No. }\end{array}$ & $\begin{array}{c}\text { Speed } \\
(\mathrm{rpm})\end{array}$ & $\begin{array}{c}\text { Feed } \\
(\mathrm{mm} / \mathrm{rev})\end{array}$ & $\begin{array}{c}\text { Depth of } \\
\text { Cut }(\mathrm{mm})\end{array}$ \\
\hline 1 & 400 & 0.06 & 0.5 \\
\hline 2 & 400 & 0.06 & 1.0 \\
\hline 3 & 400 & 0.06 & 1.5 \\
\hline 4 & 400 & 0.12 & 0.5 \\
\hline 5 & 400 & 0.12 & 1.0 \\
\hline 6 & 400 & 0.12 & 1.5 \\
\hline 7 & 400 & 0.18 & 0.5 \\
\hline 8 & 400 & 0.18 & 1.0 \\
\hline 9 & 400 & 0.18 & 1.5 \\
\hline 10 & 600 & 0.06 & 0.5 \\
\hline 11 & 600 & 0.06 & 1.0 \\
\hline 12 & 600 & 0.06 & 1.5 \\
\hline 13 & 600 & 0.12 & 0.5 \\
\hline 14 & 600 & 0.12 & 1.0 \\
\hline 15 & 600 & 0.12 & 1.5 \\
\hline 16 & 600 & 0.18 & 0.5 \\
\hline 17 & 600 & 0.18 & 1.0 \\
\hline 18 & 600 & 0.18 & 1.5 \\
\hline 19 & 800 & 0.06 & 0.5 \\
\hline 20 & 800 & 0.06 & 1.0 \\
\hline 21 & 800 & 0.06 & 1.5 \\
\hline 22 & 800 & 0.12 & 0.5 \\
\hline 23 & 800 & 0.12 & 1.0 \\
\hline 24 & 800 & 0.12 & 1.5 \\
\hline 25 & 800 & 0.18 & 0.5 \\
\hline 26 & 800 & 0.18 & 1.0 \\
\hline 27 & 800 & 0.18 & 1.5 \\
\hline
\end{tabular}

Table 4. Taguchi $\mathrm{L}_{27}$ orthogonal array

\section{EXPERIMENTAL PROCEDURE}

In presented research work experimental setup consist $\mathrm{CNC}$ lathe machine, tungsten carbide insert, work piece, micrometer and surface roughness tester.

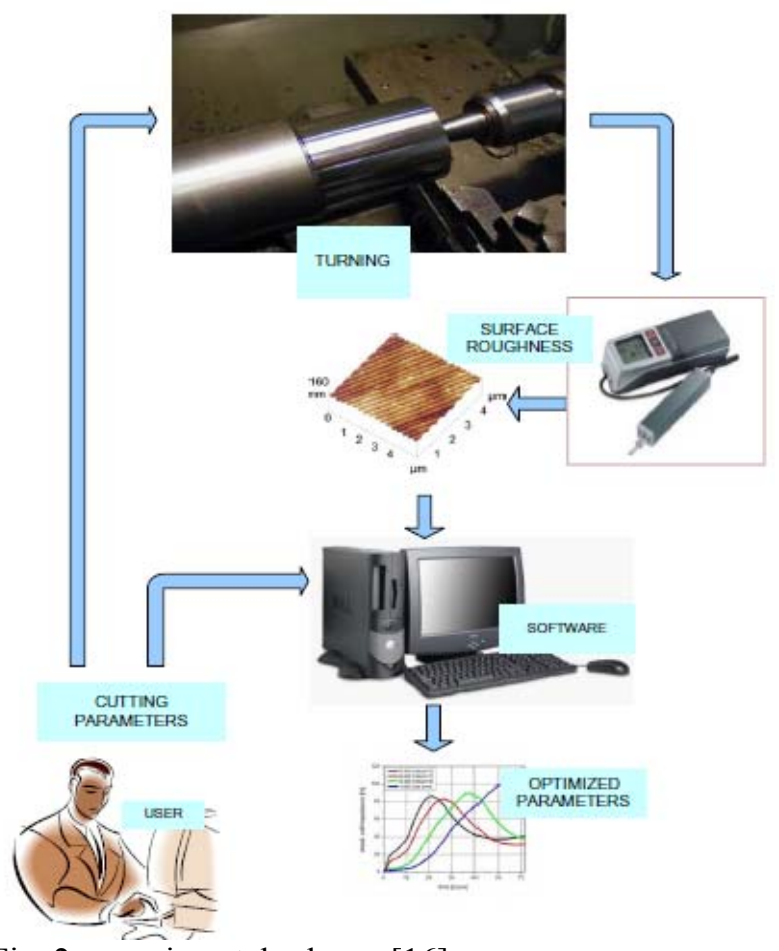

Fig. 2. experimental scheme [16] 
Fig 2. shows the experimental arrangement and a graphical abstraction of the process is shown in fig 3.Turning operation is performed on $16 \mathrm{MnCr} 5$ material work piece in dry environment. There are total 27 experiments are carried on work piece with changing levels of three factors in each experiment. After that surface roughness was measured of each cut produced in different experiments.

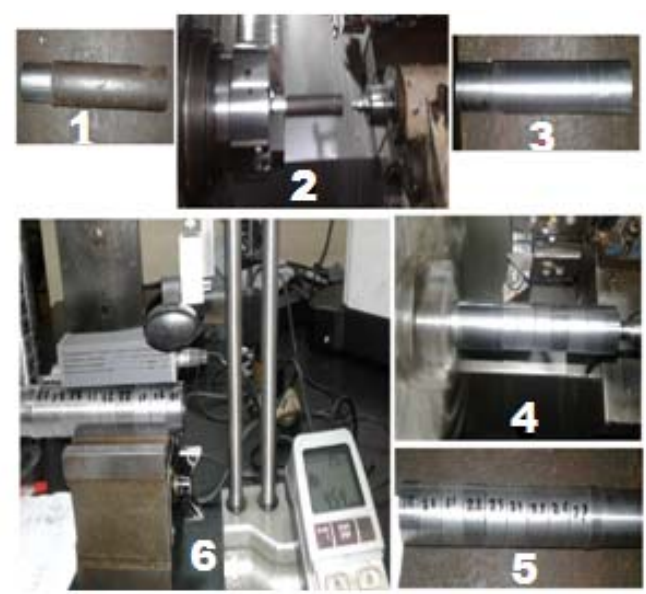

Fig. 3. Graphical abstract

\subsection{CNC Lathe Machine}

$\mathrm{CNC}$ machine used in turning operation was universal turning machine MIDAS $8 \mathrm{i}$ by GALAXY MACHINARY PVT. LTD Rajkot. Turning operation is carried out on this machine, a dry environment was chosen because of environment safety. Fig 4 shows
CNC machine used in turning process.

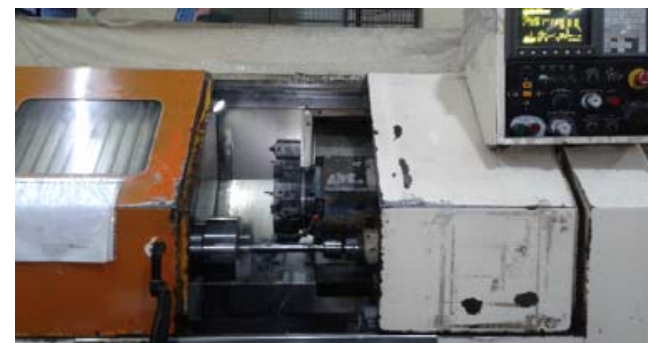

Fig. 4. CNC machine

\subsection{CNC lathe machine specification}

$\mathrm{CNC}$ lathe is used in this process is shown in fig 4 and the specification of machine is given in Table 5 .

\begin{tabular}{|l|l|}
\hline Turning diameter $(\max )$ & $280 \mathrm{~mm}$ \\
\hline Turning length $(\max )$ & $522 \mathrm{~mm}$ \\
\hline Speed & $40-4000 \mathrm{rpm}$ \\
\hline No. of tool stations & 8 \\
\hline Tailstock base travel & $339 \mathrm{~mm}$ \\
\hline CNC package & FANUC Oi “T” \\
\hline
\end{tabular}

Table 5. Specifications of CNC lathe used

\section{RESULT AND DISCUSSION}

The experimental results for average surface roughness, $\mathrm{R}_{\mathrm{a}}$ corresponding to experimental layout using $\mathrm{L}_{27}$, orthogonal array are listed in Table 6. Value for surface roughness represents the average value of three readings.

\begin{tabular}{|c|c|c|c|c|c|c|}
\hline Sl. $\mathbf{N o}$ & $\mathbf{E x} . \mathbf{N o}$ & $\mathbf{N} \mathbf{( r p m )}$ & $\mathbf{f}(\mathbf{m m} / \mathbf{r e v})$ & $\mathbf{d}(\mathbf{m m})$ & $\mathbf{R a}(\boldsymbol{\mu m})$ & $\mathbf{S N R}_{\mathbf{R a}}(\mathbf{d b})$ \\
\hline 1 & 27 & 400 & 0.06 & 0.5 & 4.53 & -13.1411 \\
\hline 2 & 18 & 400 & 0.06 & 1.0 & 3.42 & -10.6551 \\
\hline 3 & 9 & 400 & 0.06 & 1.5 & 5.61 & -14.9638 \\
\hline 4 & 24 & 400 & 0.12 & 0.5 & 4.92 & -13.8216 \\
\hline 5 & 15 & 400 & 0.12 & 1.0 & 4.97 & -13.9096 \\
\hline 6 & 6 & 400 & 0.12 & 1.5 & 1.92 & -5.5751 \\
\hline 7 & 21 & 400 & 0.18 & 0.5 & 5.93 & -15.4317 \\
\hline 8 & 12 & 400 & 0.18 & 1.0 & 3.44 & -10.6805 \\
\hline 9 & 3 & 400 & 0.18 & 1.5 & 1.74 & -4.9103 \\
\hline 10 & 26 & 600 & 0.06 & 0.5 & 4.36 & -12.8295 \\
\hline 11 & 17 & 600 & 0.06 & 1.0 & 4.02 & -12.0195 \\
\hline 12 & 8 & 600 & 0.06 & 1.5 & 1.36 & -2.7976 \\
\hline 13 & 23 & 600 & 0.12 & 0.5 & 6.86 & -16.7011 \\
\hline 14 & 14 & 600 & 0.12 & 1.0 & 1.72 & -4.7609 \\
\hline 15 & 5 & 600 & 0.12 & 1.5 & 1.07 & -0.5877 \\
\hline 16 & 20 & 600 & 0.18 & 0.5 & 4.59 & -13.2173 \\
\hline 17 & 11 & 600 & 0.18 & 1.0 & 2.01 & -5.4832 \\
\hline 18 & 2 & 600 & 0.18 & 1.5 & 2.36 & -7.4950 \\
\hline 19 & 25 & 800 & 0.06 & 0.5 & 3.51 & -10.8565 \\
\hline 20 & 16 & 800 & 0.06 & 1.0 & 2.26 & -7.1587 \\
\hline 21 & 7 & 800 & 0.06 & 1.5 & 2.07 & -6.2351 \\
\hline 22 & 22 & 800 & 0.12 & 0.5 & 1.82 & -5.2964 \\
\hline 23 & 13 & 800 & 0.12 & 1.0 & 1.16 & -1.1381 \\
\hline 24 & 4 & 800 & 0.12 & 1.5 & 1.12 & -0.7485 \\
\hline 25 & 19 & 800 & 0.18 & 0.5 & 2.16 & -6.6083 \\
\hline 26 & 10 & 800 & 0.18 & 1.0 & 1.43 & -3.1672 \\
\hline 27 & 1 & 800 & 0.18 & 1.5 & 0.99 & 0.2646 \\
\hline
\end{tabular}

Table 6. L27, Surface Roughness and S/N ration 


\begin{tabular}{|c|c|c|c|}
\hline Level & $\mathrm{N}$ & $\mathrm{f}$ & $\mathrm{d}$ \\
\hline 1 & -11.454 & -10.073 & -11.989 \\
\hline 2 & -8.432 & -6.949 & -7.664 \\
\hline 3 & -4.549 & -7.414 & -4.783 \\
\hline Delta & 6.905 & 3.124 & 7.206 \\
\hline Rank & 2 & 3 & 1 \\
\hline
\end{tabular}

Table 7. Response Table for S/N Ratios

\begin{tabular}{|c|c|c|c|}
\hline Level & $\mathrm{N}$ & $\mathrm{f}$ & $\mathrm{d}$ \\
\hline 1 & 4.046 & 3.458 & 4.292 \\
\hline 2 & 3.136 & 2.831 & 2.694 \\
\hline 3 & 1.827 & 2.719 & 2.021 \\
\hline Delta & 2.219 & 0.739 & 2.271 \\
\hline Rank & 2 & 3 & 1 \\
\hline
\end{tabular}

Table 8. Response Table for S/N Ratios

Table 7 and Table 8 show the response tables for $\mathrm{S} / \mathrm{N}$ ratio and Means. Tables show the rank of factors according to their effect on response. A factor which has high delta value shows low rank value.

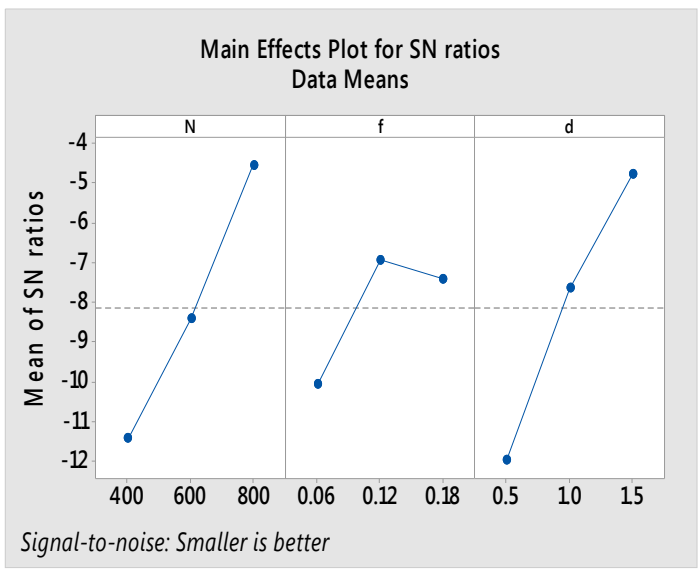

Fig. 5. Main effect plot for $\mathrm{S} / \mathrm{N}$ ratio

Main effect plot shows the mean of surface roughness is decreases with increase in speed, feed and depth of cut. Mean of $\mathrm{S} / \mathrm{N}$ ratio increases with increase in speed, for feed first increases up to feed $0.12 \mathrm{~mm} / \mathrm{rev}$ and then decreases. $\mathrm{S} / \mathrm{N}$ ratio increases with depth of cut.

The values ofthe surface roughness obtained from the 39 experimental trials, models presented in the work plotted in Fig 9.

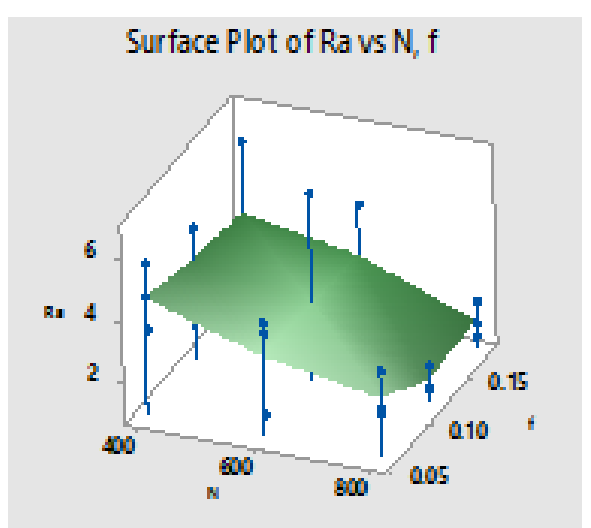

Fig. 6. Surface Plot of Ra vs N, f

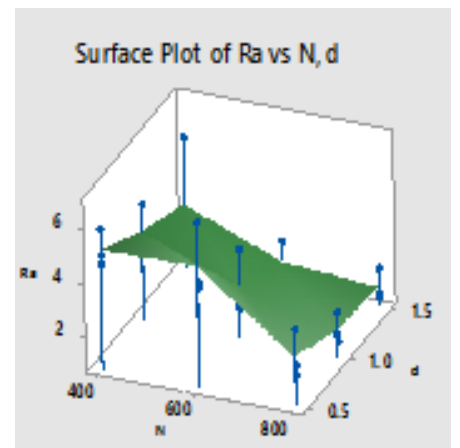

Fig. 7. Surface Plot of Ra vs N, d

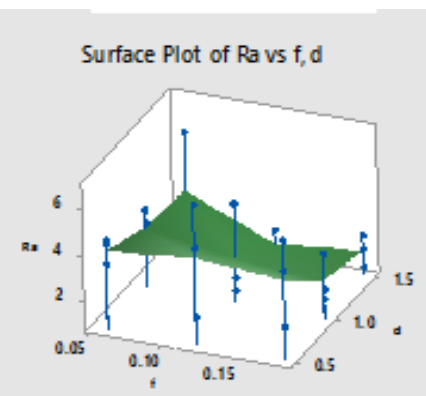

Fig. 8. Surface Plot of Ra vs f, d

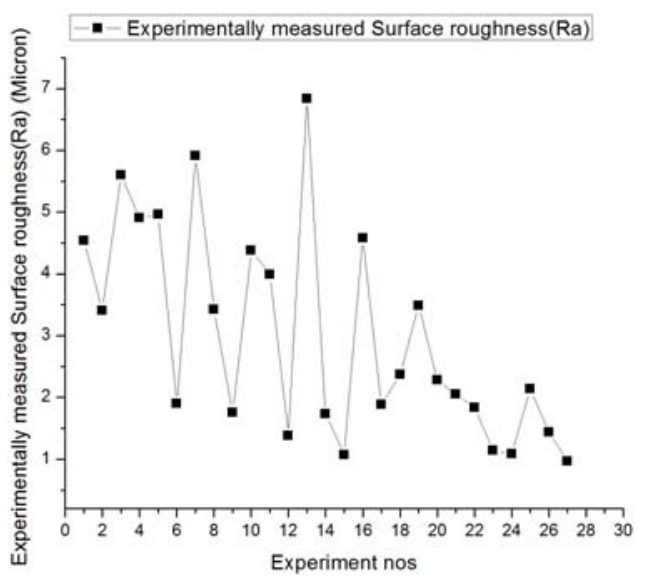

Fig. 9. Graph between experimental surface roughness and no of experiments perform

\section{REGRESSION ANALYSIS} is:

Regression Equation obtained from regression analysis

$$
R_{a}=9.34-0.00555 \times N-6.16 \times f-2.271 \times d
$$

\begin{tabular}{|c|c|c|c|c|c}
\hline Term & Coef & SE Coef & T-Value & P-Value & VIF \\
\hline Constant & 9.34 & 1.08 & 8.62 & 0.000 & \\
\hline $\mathrm{N}$ & -0.00555 & 0.00129 & -4.30 & 0.000 & 1.00 \\
\hline $\mathrm{f}$ & -6.16 & 4.30 & -1.43 & 0.165 & 1.00 \\
\hline $\mathrm{d}$ & -2.271 & 0.516 & -4.41 & 0.000 & 1.00 \\
\hline
\end{tabular}

Table 9. Regression analysis coefficient

\section{ANOVA}

The analysis of variance is used to find out which factor is more significant effect output response.

Table 10 shows depth of cut $(P=0.001)$ has highest effect on surface roughness. Second highest 
effective factor is speed $(\mathrm{P}=0.002)$ and feed $(\mathrm{P}=$ 0.347 ) has least effective factor for surface roughness.

\begin{tabular}{|c|c|c|c|c|c|c|}
\hline \multicolumn{3}{|c|}{ Model Summary } & \multirow{2}{*}{\multicolumn{2}{|c|}{ R-sq(adj) }} & \\
\hline \multirow{2}{*}{\multicolumn{2}{|c|}{$\begin{array}{l}\mathrm{S} \\
1.13113\end{array}$}} & \multirow{2}{*}{$\begin{array}{l}\text { R-sq } \\
66.03 \%\end{array}$} & & & R-sq( & red) \\
\hline & & & \multicolumn{2}{|c|}{$55.84 \%$} & \multicolumn{2}{|c|}{$38.09 \%$} \\
\hline 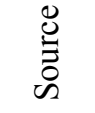 & 告 & 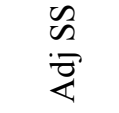 & $\bar{\nabla}^{2} \sum^{\infty}$ & 山 $\frac{\mathscr{O}}{\frac{\pi}{J}}$ & $n^{\prime} \frac{\stackrel{0}{\Xi}}{>}$ & ○゚ \\
\hline $\mathrm{N}$ & 2 & 22.394 & 11.197 & 8.75 & 0.002 & 29.73 \\
\hline f & 2 & 2.854 & 1.427 & 1.12 & 0.347 & 3.78 \\
\hline d & 2 & 24.493 & 12.246 & 9.57 & 0.001 & 32.51 \\
\hline Error & 20 & 25.589 & 1.279 & & & 33.97 \\
\hline Total & 26 & 75.330 & & & & \\
\hline
\end{tabular}

Table 10. ANOVA Table for $\mathrm{R}_{\mathrm{a}}$

\section{CONCLUSIONS}

Issues related with surface roughness during high speed machining of $16 \mathrm{MnCr} 5$ steel has been reported in this paper. Turning experiments were conducted at different speeds ranging i,e $(400 \mathrm{rpm}, 600 \mathrm{~m} / \mathrm{min}, 8000$ rpm). From investigation it was observed that depth of cut has highest effect on surface roughness followed by speed. Feed rate has lowest effect on surface roughness and Minimum surface roughness of were obtained at speed $800 \mathrm{rpm}$, feed $0.12 \mathrm{~mm} / \mathrm{rev}$ and depth of cut 1.5 $\mathrm{mm}$.During the investigation no major signs of tool damages were observed and Surface roughness obtained corresponding to optimum cutting parameters was $0.7543 \mu \mathrm{m} .3-\mathrm{D}$ figure represent effect of the turning parameters on surface roughness

\section{REFERENCES}

[1] Carmita Camposeco-Negrete "Optimization of cutting parameters for minimizing energy consumption in turning of AISI 6061 T6 using Taguchi methodology and ANOVA" Journal of Cleaner Production 53 (2013) 195-203

[2] S. Athreya, Venkatesh, "application of Taguchi method for optimization of process parameters in improving the surface roughness of lathe facing operation" International Refereed Journal of Engineering and Science (IRJES).1(3) 2012:13-19.

[3] D. Philip Selvaraj, P. Chandramohan , M. Mohanraj. "Optimization of surface roughness, cutting force and tool wear of nitrogen alloyed duplex stainless steel in a dry turning process using Taguchi method", Measurement 49 (2014) 205215.

[4] K. Adarsh Kumar, Ch.Ratnam, BSN Murthy, B.Satish Ben,K. Raghu Ram Mohan Reddy.“ Optimisation of surface roughness in face turning operation in machining of EN-8" International Journal of Engineering Science and emerging technology Vol. 2, issue-4, 807-812, July-Aug 2012.

[5] Chorng-Jyh Tzeng, Yu-Hsin Lin, Yung-Kuang Yang, Ming-Chang Jeng. "Optimization of turning operations with multiple performance characteristics using the Taguchi method and Grey relational analysis" journal of materials processing technology 209 ( $\left.\begin{array}{llll}2 & 0 & 0 & 9\end{array}\right)$ 27532759.

[6] S. Arul,D.Samuel Raj,L.Vijayaraghavan, "Modeling and optimization of process parameters for defect toleranced drilling of GFRP composites", Materials and Manufacturing Process. 21 (4) (2006) 357-365.

[7] M.P. Jenarthanan, R. Jeyapaul, "Evaluation of machinability index on milling of GFRP composites with different fibre orientations using solid carbide end mill with modified helix angles", Int. J. Eng. Sci. Technol. 6 (4) (2014) 110.

[8] Saadat Ali Rizvi1, Wajahat Ali, Optimization of Machining Parameters in Dry Turning of IS 2062 with Taguchi Technique, IJIRSET, Vol. 4, Issue 8,(2015), 7722-7732.

[9] R. Suresh, S. Basavarajappa, V. N. Gaitonde, G.L. Samuel, Machinability investigations on hardened AISI 4340 steel using coated carbide insert, Int. J. Refract. Metals Hard Mater. 33 (2012) 75-86.

[10] S. Z. Chavoshi, M. Tajdari, Surface roughness modelling in hard turning operation of AISI 4140 using CBN cutting tool, Int. J. Mater. Form. 3 (4) (2010) 233-239.

[11] Anil Gupta, Hari singh, Aman Aggarwal "Taguchi-fuzzy multi output optimization (MOO) in high speed CNC truing of AISI P-20 tool steel", Expert System with Application : An International Journal, Vol.38 Issue 6, (2011),6822-6828.

[12] Y. Sahin, A. R. Motorcu, Surface roughness model for machining mild steel with coated carbide tool, Mater. Des. 26 (2005) 321-326.

[13] Saadat Ali Rizvi, Wajahat Ali," Optimization of machining parameters affecting surface roughness of EN8 Steel in CNC Turning by Using the Taguchi Technique" Journal of Mechanical and Mechanics Engineering Volume 2 Issue 3, (2016),59-71

[14] Murat Sarıkaya, Abdulkadir Güllü, "Taguchi design and response surface methodology based analysis of machining parameters in $\mathrm{CNC}$ turning under MQL" Journal of Cleaner Production 65 (2014) 604-616.

[15] M.VenkataRamana,Y.ShanmukaAditya,“Optimi zation and influence of process parameters on surface roughness in turning of titanium alloy" Materials Today: Proceedings 4 (2017) 18431851

[16] Ilhan Asilturk, Harun Akkus, Determining the effect of cutting parameters on surface roughness in hard turning using the Taguchi method, Measurement 44 (2011) 1697-1704.

Authors: Saadat Ali Rizvi ${ }^{\mathrm{a}}$, Wajahat Ali ${ }^{\mathrm{b}},{ }^{\mathrm{a}}$ Research Scholar, Department of Mechanical Engineering, IIT (BHU), Varanasi (U.P) and faculty member in UP, Jamia Millia Islamia, New Delhi., Mobile No: 00917531026305, ${ }^{\mathrm{b}}$ Mechanical Engineering Department, SCRIET, CCS University, Meerut E-mail: sarizvi1@jmi.ac.in, saritbhu@gmail.com 